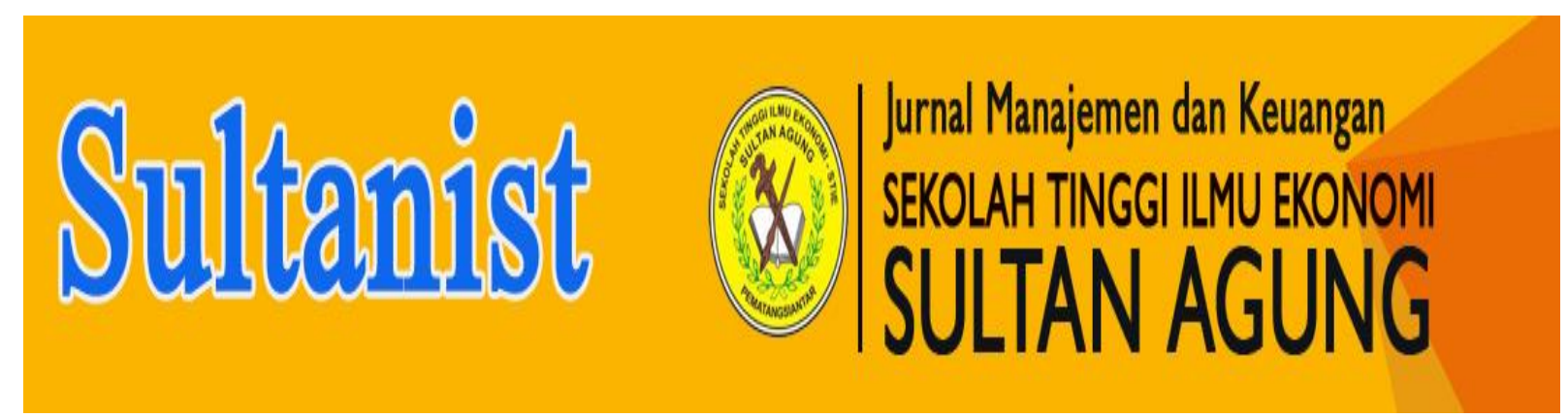

\title{
PENGARUH LIKUIDITAS, SOLVABILITAS DAN PROFITABILITAS TERHADAP HARGA SAHAM PADA PERUSAHAAN YANG TERDAFTAR DALAM INDEKS LQ 45
}

\author{
Oleh : \\ Tri Ade Tiya \\ S1 Akuntansi \\ Yansen Siahaan, Jubi, Sepbeariska Manurung
}

Abstrak

Tujuan dari penelitian ini adalah untuk mengetahui gambaran likuiditas, solvabilitas, profitabilitas dan harga sahamserta pengaruh likuiditas, sovabilitas dan profitabilitas terhadap harga saham pada Perusahaan yang Terdaftar Dalam Indeks LQ 45. Penelitian ini dilakukan dengan metode analisis deskriptif kualitatif dan analisis deskriptif kuantitatif. Pengumpulan data dilakukan dengan metode dokumentasi. Teknik analisis yang digunakan adalah regresi linier berganda, koefisien korelasi, koefisien determinasi, uji hipotesis.

Hasil regresi penelitian ini adalah likuiditas, solvabilitas dan profitabilitas berpengaruh negatif terhadap harga saham pada Perusahaan yang Terdaftar Dalam Indeks LQ 45. Hasil analisis koefisien korelasi dan koefisien determinasi diketahui bahwa terdapat hubungan yang sedang antara likuiditas, solvabilitas dan profitabilitas terhadap harga saham dan harga saham lebih banyak dipengaruhi oleh faktor lain yang tidak diteliti dalam penelitian ini. Hasil uji $F$ menunjukkan bahwa likuiditas, solvabilitas dan profitabilitas berpengaruh signifikan terhadap harga saham pada Perusahaan yang Terdaftar Dalam Indeks LQ 45Tahun 2013-2017. Hasil uji t menunjukkan bahwa secara parsial likuiditas dan solvabilitas berpengaruh signifikan dan profitabilitas berpengaruh tidak signifikan terhadap harga saham pada Perusahaan yang Terdaftar dalam Indeks LQ 45.

Saran yang dapat diberikan adalah Sebaiknya perusahaan mengelola aset lancar dengan optimal untuk meningkatkan pendapatan, mengendalikan penggunaan utang, dan membagikan dividen kepada investor agar investor tertarik menanamkan modalnya di perusahaan.

Kata Kunci: Likuiditas, Solvabilitas, Profitabilitas dan Harga Saham

Abstract

The purpose of this research is to describe liquidity, solvability, profitability and stock pricesand to know influence of liquidity, solvability and profitabilityto stock prices at the Companieslisted in LQ 45 Index. The research was using qualitative desriptive analysis and quantitative desriptive analysis. The data collection was using documentation. The analysis techniques used are multiple linear regression, correlation coeffient, coefficient of determination, hypothesis testing.

The result of regression are liquidity, solvability and profitability have a negative effect on stock prices at the Companies listed in the LQ 45 Index. The results analysis of the correlation coefficient and determination coefficient is known that there is a medium relationship between liquidity, solvability and profitability of stock prices and stock prices are more influenced by other factors not examined in this research. The results of $F$ testit is known that liquidity, solvability and profitability have a significant effect on stock prices at the Companies listed in the LQ 45 Index simultaneously. The results of the $t$ test it is known that partially liquidity and solvability have a significant effect and profitability has no significant effect on stock prices at the Companies listed in the LQ 45 Index.

The suggestion of this research is that the company should manage current assets optimally to increase revenue, control the use of debt, and distribute dividends to investors so that investors are interested in investing capital in the company.

Keywords: Liquidity, Solvability, Profitability and Stock Prices

\section{PENDAHULUAN}

\subsection{Latar Belakang Masalah}

Pasar modal penting bagi perekonomian sebagai sarana bagi pendanaan usaha dan sebagai sarana bagi masyarakat untuk berinvestasi pada instrumen keuangan. Harga saham di bursa efek tidak selamanya tetap, adakalanya meningkat dan bisa pula menurun, tergantung pada kekuatan permintaan dan penawaran. Di sisi lain, kenaikan dan penurunan harga bisa terjadi karena faktor fundamental, psikologis, faktor internal maupun eksternal. Dalam menentukan harga saham dapat menggunakan harga penutupan (closing price).

Salah satu informasi yang dapat dilihat oleh pihak investor dalam menanamkan investasi pada suatu perusahaan adalah data akuntansi. Untuk memahami data akuntansi dapat dilakukan dengan cara menganalisis laporan 
keuangan dengan teknik analisis rasio keuangan. Rasio keuangan yang dapat digunakan adalah likuiditas, solvabilitas dan profitabilitas.

Likuiditas menunjukkan kemampuan perusahaan dalam memenuhi kewajiban jangka pendek yang segera jatuh tempo. Likuiditas dapat diukur dengan menggunakan rasio lancar (current ratio). Solvabilitas menunjukkan kemampuan perusahaan dalam memenuhi seluruh kewajibannya, baik kewajiban jangka panjang maupun kewajiban jangka pendek. Solvabilitas dapat diukur dengan menggunakan Debt to Equity Ratio (DER). Profitabilitas menunjukkan kemampuan perusahaan dalam menghasilkan labadengan sumber-sumber yang dimiliki perusahaan. Salah satu parameter ukur profitabilitas adalah pengembalian atas ekuitas (return on equity).

$$
\text { Tabel } 1.1
$$

Gambaran Rata-rata Likuiditas, Solvabilitas,

Profitabilitas dan Harga Saham Perusahaan yang Terdaftar Dalam Indeks LQ 45 Tahun 2013-2017

\begin{tabular}{|c|c|c|c|c|}
\hline \multirow{2}{*}{ Tahun } & Likuiditas & Solvabilitas & Profitabilitas & $\begin{array}{c}\text { Harga } \\
\text { Saham } \\
\text { (Kali) }\end{array}$ \\
\cline { 2 - 4 } & CR (Kali) & DER (Kali) & ROE (Kali) & 5.269 \\
\hline $\mathbf{2 0 1 3}$ & 2,074 & 0,852 & 0.182 & 5.828 \\
\hline $\mathbf{2 0 1 4}$ & 1,991 & 0.863 & 0,182 & 4.615 \\
\hline $\mathbf{2 0 1 5}$ & 2,071 & 0,910 & 0.134 & 5.113 \\
\hline $\mathbf{2 0 1 6}$ & 2,022 & 0,829 & 0.137 & 5.079 \\
\hline $\mathbf{2 0 1 7}$ & 2,316 & 0,675 & 0,147 & $\mathbf{0 . 1 8 1}$ \\
\hline $\begin{array}{c}\text { Rata- } \\
\text { rata }\end{array}$ & $\mathbf{2 , 0 9 5}$ & $\mathbf{0 , 8 2 6}$ & $\mathbf{0 , 1 5 6}$ & $\mathbf{5 . 1 8}$ \\
\hline
\end{tabular}

Sumber: Laporan keuangan perusahaan LQ 45 (www.idx.co.id) Data diolah

Berdasarkan Tabel 1.1 di atas dapat diketahui bahwa rata-rata likuiditas yang diukur dengan rasio lancar (current ratio) berfluktuasi dan cenderung meningkat diikuti dengan penurunan harga saham. Hal ini tidak sesuai dengan pendapat Fahmi (2015:166), yang menyatakan perusahaan yang memiliki rasio likuiditas tinggi akan diminati para investor dan akan berimbas pula pada harga saham yang cenderung akan naik karena tingginya permintaan. Rata-rata Solvabilitas yang diukur dengan DER mengalami fluktuasi dan cenderung menurun diikuti dengan penurunan harga saham. Hal ini tidak sejalan dengan pendapat Brigham dan Joel (2006:24), yang menyatakan tingkat utang yang lebih tinggi akan meningkatkan risiko perusahaan, dan hal tersebut akan menaikkan biaya ekuitas dan dapat menurunkan harga saham. Rata-rata profitabilitas yang diukur dengan ROE mengalami fluktuasi dan cenderung menurun diikuti dengan penurunan harga saham. Namun pada tahun 2016-2017 rata-rata profitabilitas meningkat dan harga saham menurun. Hal ini tidak sesuai dengan pendapat Brigham dan Joel (2010:133), yang menyatakan pemegang saham pastinya ingin mendapatkan tingkat pengembalian yang tinggi atas modal yang mereka investasikan dan ROE menunjukkan tingkat yang mereka peroleh. Jika ROE tinggi, maka harga saham juga cenderung akan tinggi dan tindakan yang meningkatkan ROE kemungkinan juga akan meningkatkan harga saham.

\subsection{Rumusan Masalah}

1. Bagaimana gambaran likuiditas, solvabilitas, profitabilitas dan harga saham pada Perusahaan yang terdaftar dalam indeks LQ 45.

2. Bagaimana pengaruh likuiditas, solvabilitas dan profitabilitas terhadap harga saham pada Perusahaan yang terdaftar dalam indeks LQ 45 baik secara simultan maupun parsial.

\subsection{Tujuan Penelitian}

1. Untuk mengetahui gambaran likuiditas, solvabilitas, profitabilitas dan harga saham pada Perusahaan yang terdaftar dalam indeks LQ 45.

2. Untuk mengetahui pengaruh likuiditas, solvabilitas dan profitabilitas terhadap harga saham pada Perusahaan yang terdaftar dalam indeks LQ 45 baik secara simultan maupun parsial.

\subsection{Metode Penelitian}

Penelitian ini menggunakan data sekunder dengan cara mengakses dari situs http://www.idx.co.id.Desain penelitian ini adalah penelitian kepustakaan (library research). Teknik analisa data yang digunakan adalah uji asumsi klasik, analisa deskriptif kualitatif, analisa deskriptif kuantitatif.

\section{LANDASAN TEOR}

\subsection{Akuntans}

Menurut Yadiati dan Ilham (2010:6), "akuntansi adalah suatu sistem yang mengidentifikasi, mencatat, dan mengomunikasikan kejadian ekonomi dari suatu organisasi kepada pihak yang berkepentingan".

Sedangkan menurut Rudianto (2009:4), "akuntansi adalah sebuah sistem informasi yang menghasilkan informasi keuangan kepada pihak-pihak yang berkepentingan mengenai aktivitas ekonomi dan kondisi suatu perusahaan".

\subsection{Tujuan Akuntansi}

Menurut Soemarso (2009:8), tujuan utama akuntansi adalah menyajikan informasi ekonomi (economic information) dari suatu kesatuan ekonomi (economic entity) kepada pihak-pihak yang berkepentingan.

Sedangkan menurut Harahap

(2011:122),tujuan akuntansi sebagai berikut:

1. Membuat keputusan yang menyangkut penggunaan kekayaan yang terbatas dan untuk menetapkan tujuan. 
2. Mengarahkan dan mengontrol secara efektif sumber daya manusia dan faktor produksi lainnya.

3. Memelihara dan melaporkan pengumuman terhadap kekayaan.

4. Membantu fungsi dan pengawasan sosial.

\subsection{Analisa Laporan Keuangan}

Menurut Harahap (2008:189), "analisis laporan keuangan berarti menguraikan pospos laporan keuangan menjadi unit informasi yang lebih kecil dan melihat hubungannya yang bersifat signifikan atau yang mempunyai makna antara satu dengan yang lain, baik antara data kuantitatif maupun data nonkuantitatif dengan tujuan untuk mengetahui kondisi keuangan lebih dalam yang sangat penting dalam proses menghasilkan keputusan yang tepat".

Sedangkan menurut Hery (2014:113), "analisis laporan keuangan merupakan suatu proses membedah laporan keuangan ke dalam unsur-unsurnya dan menelaah masing-masing dari unsur tersebut dengan tujuan untuk memperoleh pengertian dan pemahaman yang baik dan tepat atas laporan keuangan itu sendiri".

\subsection{Likuiditas}

Menurut Brigham dan Joel (2010:134), "likuiditas adalah rasio yang menunjukkan hubungan antara kas dan aset lancar perusahaan lainnya dengan kewajiban lancarnya".

Sedangkan menurut Hery (2017:284), "likuiditas adalah rasio yang menunjukkan kemampuan perusahaan dalam memenuh kewajiban atau membayar utang jangka pendeknya".

\subsection{Solvabilitas}

Menurut Hery (2017:295), "solvabilitas atau leverage merupakan rasio yang digunakan untuk mengukur kemampuan perusahaan dalam memenuhi seluruh kewajibannya, baik kewajiban jangka pendek maupun kewajiban jangka panjang".

Selain itu menurut Kasmir (2015:113), "solvabilitas merupakan rasio yang digunakan untuk mengukur sampai sejauh mana aktiva perusahaan dibiayai oleh utang".

\subsection{Profitabilitas}

Menurut Hery (2017:312), "profitabilitas merupakan rasio yang menggambarkan kemampuan perusahaan dalam menghasilkan laba melalui semua kemampuan dan sumber daya yang dimilikiny, yaitu yang berasal dari kegiatan penjualan, penggunaan aset, maupun penggunaan modal".

Selain itu, menurut Sudana (2011:22), "profitabilitas mengukur kemampuan perusahaan untuk menghasilkan laba dengan menggunakan sumber-sumber dana yang dimiliki perusahaan, seperti aktiva, modal, penjualan perusahaan".

\subsection{Harga Saham}

Menurut Budiman (2017:8), "harga saham adalah harga yang terbentuk berasal dari kesepakatan antara pemilik saham dengan pembeli saham".

Sedangkan, menurut Widoatmojo (2005:102), "harga saham merupakan harga jual dari investor yang satu kepada investor lain setelah saham tersebut dicantumkan di bursa, baik bursa utama, maupun OTC (Over The Counter Market)".

\subsection{Pengaruh Likuiditas, Solvabilitas dan Profitabilitas Terhadap Harga Saham}

Menurut Brigham dan Joel (2010:132), "data akuntansi memang mempengaruhi harga saham, dan data-data ini dapat digunakan untuk memahami penyebab suatu perusahaan memiliki kinerja seperti sekarang dan meramalkan arah yang akan dituju".

Salah satu cara untuk memahami data akuntansi tersebut dapat dilakukan dengan cara menganalisis laporan keuangan dengan teknik analisis rasio keuangan. Beberapa rasio keuangan yang dapat digunakan adalah rasio likuiditas, solvabilitas, dan profitabilitas.

Menurut Brigham dan Joel (2010:150), "jika rasio likuiditas,manajemen aset, manajemen utang dan profitabilitas semuanya terlihat baik dan jika kondisi ini berjalan terus menerus secara stabil, maka rasio nilai pasar juga akan meninggi, harga saham kemungkinan tinggi sesuai dengan yang diperkirakan, dan manajemen telah melakukan pekerjaannya dengan baik sehingga mendapat imbalan".

\section{PEMBAHASAN}

\subsection{Analisis}

3.1.1. Analisis Deskripsi Kualitatif

3.1.1.1. Gambaran Likuiditas pada
Perusahaan yang Terdaftar Dalam Indeks LQ 45 Tahun 2013-2017

Berikut ini gambaran likuiditas Perusahan yang Terdaftar Dalam Indeks LQ 45 Tahun 203-2017 yang diukur dengan rasio lancar (current ratio) disajikan pada Tabel 3.1.

Tabel 3.1

Gambaran Rasio Lancar Perusahaan yang Terdaftar Dalam Indeks LQ 45

Tahun 2013-2017

\begin{tabular}{|c|c|c|c|c|c|c|}
\hline \multirow{2}{*}{$\begin{array}{l}\text { Kode } \\
\text { Emiten }\end{array}$} & \multicolumn{5}{|c|}{ Likuiditas (Rasio Lancar) } & \multirow{2}{*}{$\begin{array}{c}\text { Rata- } \\
\text { rata } \\
\text { (Kali) }\end{array}$} \\
\hline & $\begin{array}{l}2013 \\
\text { (Kali) }\end{array}$ & $\begin{array}{c}2014 \\
\text { (Kali) }\end{array}$ & $\begin{array}{l}2015 \\
\text { (kali) }\end{array}$ & $\begin{array}{l}2016 \\
\text { (Kali) }\end{array}$ & $\begin{array}{l}2017 \\
\text { (Kali) }\end{array}$ & \\
\hline AALI & 0,450 & 0,585 & 0,799 & 1,028 & 1,838 & 0,940 \\
\hline AKRA & 1,171 & 1,087 & 1,496 & 1,271 & 1,624 & 1,330 \\
\hline ASII & 1,242 & 1,323 & 1,379 & 1,239 & 1,229 & 1,282 \\
\hline ASRI & 0,753 & 1,137 & 0,719 & 0,898 & 0,737 & 0,849 \\
\hline BSDE & 2,667 & 2,181 & 2,732 & 2,936 & 2,373 & 2,578 \\
\hline CPIN & 3,792 & 2,241 & 2,106 & 2,173 & 2,317 & 2,526 \\
\hline ICBP & 2,411 & 2,183 & 2,326 & 2,407 & 2,428 & 2,351 \\
\hline
\end{tabular}




\begin{tabular}{|c|c|c|c|c|c|c|}
\hline \multirow[b]{2}{*}{$\begin{array}{c}\text { Kode } \\
\text { Emiten }\end{array}$} & \multicolumn{5}{|c|}{ Likuiditas (Rasio Lancar) } & \multirow{2}{*}{$\begin{array}{c}\text { Rata- } \\
\text { rata } \\
\text { (Kali) }\end{array}$} \\
\hline & $\begin{array}{l}2013 \\
\text { (Kali) }\end{array}$ & $\begin{array}{l}2014 \\
\text { (Kali) }\end{array}$ & $\begin{array}{l}2015 \\
\text { (kali) }\end{array}$ & $\begin{array}{l}2016 \\
\text { (Kali) }\end{array}$ & $\begin{array}{c}2017 \\
\text { (Kali) }\end{array}$ & \\
\hline INDF & 1,667 & 1,807 & 1,705 & 1,508 & 1,503 & 1,638 \\
\hline JSMR & 0,761 & 0,844 & 0,482 & 0,696 & 0,760 & 0,709 \\
\hline KLBF & 2,839 & 3,404 & 3,696 & 4,131 & 4,509 & 3,716 \\
\hline LPKR & 4,960 & 5,233 & 6,913 & 5,455 & 5,137 & 5,540 \\
\hline LSIP & 2,485 & 2,491 & 2,221 & 2,459 & 5,209 & 2,973 \\
\hline PTBA & 2,866 & 2,075 & 1,544 & 1,656 & 2,463 & 2,121 \\
\hline SMGR & 1,882 & 2,209 & 1,597 & 1,273 & 1,568 & 1,706 \\
\hline TLKM & 1,163 & 1,062 & 1,353 & 1,200 & 1,048 & 1,165 \\
\hline $\begin{array}{l}\text { Rata-rata } \\
\text { Per Tahun } \\
\text { (Kali) }\end{array}$ & 2,074 & 1,991 & 2,071 & 2,022 & 2,316 & - \\
\hline \multicolumn{6}{|c|}{ Nilai Rasio Lancar Minimum (Kali) } & 0,450 \\
\hline \multicolumn{6}{|c|}{ Nilai Rasio Lancar Maksimum (Kali) } & 6,913 \\
\hline \multicolumn{6}{|c|}{ Rata-rata Keseluruhan } & 2,095 \\
\hline
\end{tabular}

Dari Tabel 3.1 di atas, dapat dilihat keadaan likuiditas yang diukur dengan rasio lancar pada Perusahaan yang Terdaftar Dalam Indeks LQ 45 tahun 2013-2017 berfluktuasi dan cenderung meningkat. Hal ini disebabkan karena peningkatan aset lancar lebih besar daripada peningkatan kewajiban lancar sehingga likuiditas meningkat.

\subsubsection{Gambaran Solvabilitas pada Perusahaan yang Terdaftar Dalam Indeks LQ 45 Tahun 2013-2017}

Berikut ini gambaran solvabilitasPerusahan yang Terdaftar Dalam Indeks LQ 45 Tahun 203-2017 yang diukur dengan rasio DER disajikan dalam Tabel 3.2.

Tabel 3.2

Gambaran DER pada Perusahaan yang Terdaftar Dalam Indeks LQ 45

Tahun 2013-2016

\begin{tabular}{|c|c|c|c|c|c|c|}
\hline \multirow[b]{3}{*}{$\begin{array}{l}\text { Kode } \\
\text { Emiten }\end{array}$} & \multirow{2}{*}{\multicolumn{5}{|c|}{$\begin{array}{r}\text { Tahun 2013-2016 } \\
\text { Solvabilitas (DER) }\end{array}$}} & \multirow{3}{*}{$\begin{array}{l}\text { Rata- } \\
\text { rata } \\
\text { (Kali) }\end{array}$} \\
\hline & & & & & & \\
\hline & \multicolumn{2}{|r|}{$\begin{array}{l}\text { Sol } \\
2014 \\
\text { (Kali) }\end{array}$} & $\begin{array}{l}\text { bilitas } \\
2015 \\
\text { (kali) }\end{array}$ & $\begin{array}{l}\text { ER) } \\
2016 \\
\text { (Kali) }\end{array}$ & $\begin{array}{l}2017 \\
\text { (Kali) }\end{array}$ & \\
\hline AALI & 0,457 & 0,568 & 0,839 & 0,377 & 0,345 & 0,520 \\
\hline AKRA & 1,728 & 1,481 & 1,087 & 0,961 & 0,863 & 1,224 \\
\hline ASII & 1,015 & 0,962 & 0,940 & 0,872 & 0,891 & 0,936 \\
\hline ASRI & 1,706 & 1,656 & 1,834 & 1,808 & 1,418 & 1,685 \\
\hline BSDE & 0,683 & 0,523 & 0,630 & 0,572 & 0,574 & 0,596 \\
\hline CPIN & 0,580 & 0,906 & 0,965 & 0,710 & 0,562 & 0,745 \\
\hline ICBP & 0,603 & 0,656 & 0,621 & 0,562 & 0,556 & 0,600 \\
\hline INDF & 1,035 & 1,084 & 1,130 & 0,870 & 0,881 & 1,000 \\
\hline JSMR & 1,610 & 1,788 & 1,969 & 2,274 & 0,768 & 1,682 \\
\hline KLBF & 0,331 & 0,266 & 0,252 & 0,222 & 0,196 & 0,253 \\
\hline LPKR & 1,208 & 1,140 & 1,185 & 1,066 & 0,901 & 1,100 \\
\hline LSIP & 0,206 & 0,199 & 0,206 & 0,237 & 0,200 & 0,209 \\
\hline PTBA & 0,546 & 0,708 & 0,819 & 0,760 & 0,593 & 0,685 \\
\hline SMGR & 0,412 & 0,372 & 0,390 & 0,447 & 0,609 & 0,446 \\
\hline TLKM & 0,653 & 0,636 & 0,779 & 0,702 & 0,770 & 0,708 \\
\hline $\begin{array}{l}\text { Rata-rata } \\
\text { Per Tahun } \\
\text { (Kali) }\end{array}$ & 0,852 & 0,863 & 0,910 & 0,829 & 0,675 & - \\
\hline \multirow{2}{*}{\multicolumn{6}{|c|}{ Nilai DER Minimum (Kali) }} & 0,196 \\
\hline \multicolumn{4}{|c|}{ Nilai DER Maksimum (Kali) } & & & 2,274 \\
\hline \multicolumn{6}{|c|}{ Rata-rata Keseluruhan } & 0,826 \\
\hline
\end{tabular}

Sumber : Data Diolah

Dari Tabel 3.2 di atas, dapat dilihat keadaan solvabilitas yang di ukur dengan Debt to Equity Ratio (DER) pada Perusahaan yang Terdaftar Dalam Indeks LQ 45 tahun 2013-2017 berfluktuasi dan cenderung menurun. Hal ini disebabkan karena peningkatan total ekuitas lebih besar dari peningkatan total utang sehingga Debt to Equity Ratio (DER) menurun.

\subsubsection{Gambaran Profitabilitas pada Perusahaan yang Terdaftar Dalam Indeks LQ 45 Tahun 2013-2017}

Berikut ini gambaran profitabilitas Perusahaan yang Terdaftar Dalam Indeks LQ 45 Tahun 2013-2017 yang diukur dengan pengembalian atas ekuitas disajikan dalam Tabel 3.3.

Tabel 3.3

Gambaran Profitabilitas pada Perusahaan yang Terdaftar Dalam Indeks LQ 45 Tahun 2013-2017

\begin{tabular}{|c|c|c|c|c|c|c|}
\hline \multirow{2}{*}{$\begin{array}{c}\text { Kode } \\
\text { Emiten }\end{array}$} & \multicolumn{5}{|c|}{$\begin{array}{c}\text { Profitabilitas } \\
\text { (Pengembalian atas Ekuitas) }\end{array}$} & \multirow{2}{*}{$\begin{array}{c}\text { Rata- } \\
\text { rata } \\
\text { (Kali) }\end{array}$} \\
\hline & $\begin{array}{l}2013 \\
\text { (Kali) }\end{array}$ & $\begin{array}{l}2014 \\
\text { (Kali) }\end{array}$ & $\begin{array}{l}2015 \\
\text { (kali) }\end{array}$ & $\begin{array}{l}2016 \\
\text { (Kali) }\end{array}$ & $\begin{array}{l}2017 \\
\text { (Kali) }\end{array}$ & \\
\hline AALI & 0,185 & 0,221 & 0,059 & 0,120 & 0,114 & 0,140 \\
\hline AKRA & 0,115 & 0,133 & 0,145 & 0,130 & 0,144 & 0,133 \\
\hline ASII & 0,210 & 0,184 & 0,123 & 0,131 & 0,148 & 0,159 \\
\hline ASRI & 0,167 & 0,185 & 0,104 & 0,071 & 0,162 & 0,138 \\
\hline BSDE & 0,217 & 0,216 & 0,106 & 0,084 & 0,177 & 0,160 \\
\hline CPIN & 0,254 & 0,160 & 0,146 & 0,157 & 0,159 & 0,175 \\
\hline ICBP & 0,168 & 0,168 & 0,178 & 0,196 & 0,174 & 0,177 \\
\hline INDF & 0,089 & 0,125 & 0,086 & 0,120 & 0,110 & 0,106 \\
\hline JSMR & 0,114 & 0,106 & 0,107 & 0,110 & 0,026 & 0,093 \\
\hline KLBF & 0,232 & 0,216 & 0,188 & 0,189 & 0,177 & 0,200 \\
\hline LPKR & 0,112 & 0,178 & 0,054 & 0,056 & 0,029 & 0,086 \\
\hline LSIP & 0,116 & 0,127 & 0,085 & 0,078 & 0,094 & 0,100 \\
\hline PTBA & 0,246 & 0,233 & 0,219 & 0,192 & 0,330 & 0,244 \\
\hline SMGR & 0,246 & 0,223 & 0,165 & 0,148 & 0,067 & 0,170 \\
\hline TLKM & 0,262 & 0,249 & 0,250 & 0,276 & 0,292 & 0,266 \\
\hline $\begin{array}{c}\text { Rata-rata } \\
\text { Per Tahun } \\
\text { (Kali) }\end{array}$ & 0,182 & 0,182 & 0,134 & 0,137 & 0,147 & 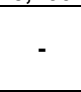 \\
\hline \multicolumn{6}{|c|}{ Nilai Pengembalian atas Ekuitas Minimum (Kali) } & 0,026 \\
\hline \multicolumn{6}{|c|}{ Nilai Pengembalian atas Ekuitas Maksimum (Kali) } & 0,330 \\
\hline \multicolumn{6}{|c|}{ Rata-rata Keseluruhan } & 0,156 \\
\hline
\end{tabular}

Sumber : Data Diolah

Dari Tabel 3.3 di atas, dapat dilihat keadaan profitabilitas yang diukur dengan pengembalian atas ekuitas pada Perusahaan yang Terdaftar Dalam Indeks LQ 45 tahun 2013-2017 berfluktuasi dan cenderung menurun. Hal ini disebabkan karena peningkatan total ekuitas lebih besar dari peningkatan laba bersih.

\subsubsection{Gambaran Harga Saham pada Perusahaan yang Terdaftar Dalam Indeks LQ 45 Tahun 2013-2017}

Berikut ini gambaran harga saham Perusahaan yang Terdaftar Dalam Indeks LQ 45 Tahun 2013-2017 disajikan pada Tabel 3.4.

Tabel 3.4

Gambaran Harga Saham pada Perusahaan yang Terdaftar Dalam Indeks LQ 45 Tahun 2013-2017

\begin{tabular}{|c|c|c|c|c|c|c|}
\hline \multirow{2}{*}{$\begin{array}{c}\text { Kode } \\
\text { Emiten }\end{array}$} & \multicolumn{5}{|c|}{ Harga Saham (Rp) } & \multirow{2}{*}{$\begin{array}{l}\text { Rata- } \\
\text { rata } \\
(\mathbf{R p})\end{array}$} \\
\hline & 2013 & 2014 & 2015 & 2016 & 2017 & \\
\hline AALI & 23.916 & 23.107 & 15.103 & 16.775 & 13.150 & 18.410 \\
\hline AKRA & 4.375 & 4.120 & 7.175 & 6.000 & 6.350 & 5.604 \\
\hline ASIII & 6.800 & 7.425 & 6.000 & 8.275 & 8.300 & 7.360 \\
\hline ASRI & 430 & 560 & 343 & 352 & 356 & 408 \\
\hline BSDE & 1.290 & 1.805 & 1.800 & 1.755 & 1.700 & 1.670 \\
\hline CPIN & 3.375 & & & 3.090 & 3.000 & \\
\hline ICBP & 5.100 & 6.550 & 6.738 & 8.575 & 8.900 & 7.173 \\
\hline INDF & 6.600 & 6.750 & 5.175 & 7.925 & 7.625 & 6.815 \\
\hline JSN & & & & & 6.400 & 5.536 \\
\hline KLBF & 1.250 & 1.830 & 1.320 & 1.515 & 1.690 & 1.521 \\
\hline LPKR & 910 & 1.020 & 1.035 & 720 & 488 & 835 \\
\hline LSIP & 1.930 & 1.8 & 1.320 & 1.740 & 1.420 & 1.660 \\
\hline PTBA & 2.040 & 2.500 & 905 & 2.500 & 2.460 & 2.081 \\
\hline
\end{tabular}




\begin{tabular}{|c|c|c|c|c|c|c|}
\hline \multirow{2}{*}{$\begin{array}{l}\text { Kode } \\
\text { Emiten }\end{array}$} & \multicolumn{5}{|c|}{ Harga Saham (Rp) } & \multirow{2}{*}{$\begin{array}{l}\text { Rata- } \\
\text { rata } \\
(\mathbf{R p})\end{array}$} \\
\hline & 2013 & 2014 & 2015 & 2016 & 2017 & \\
\hline SMGR & 14.150 & 16.200 & 11.400 & 9.175 & 9.900 & 12.165 \\
\hline TLKM & 2.150 & 2.845 & 3.105 & 3.980 & 4.440 & 3.304 \\
\hline $\begin{array}{c}\text { Rata-rata } \\
\text { Per } \\
\text { Tahun } \\
\text { (Rp) }\end{array}$ & 5.269 & 5.828 & 4.615 & 5.113 & 5.079 & - \\
\hline \multicolumn{6}{|c|}{ Nilai Harga Saham Minimum (Rp) } & $\begin{array}{r}343 \\
23916\end{array}$ \\
\hline \multicolumn{6}{|c|}{$\begin{array}{c}\text { Nilai Harga Saham Maksimum (Rp) } \\
\text { Rata-rata Keseluruhan }\end{array}$} & $\begin{aligned} 23.916 \\
5.181\end{aligned}$ \\
\hline
\end{tabular}

Sumber : Data Diolah

Dari Tabel 3.4 di atas, tampak keadaan rata-rata harga saham Perusahaan yang Terdaftar Dalam Indeks LQ 45 Tahun 20132017 mengalami fluktuasi dan cenderung menurun.

\subsubsection{Analisis Deskrisptif Kuantitatif}

3.1.2.1. Analisis Regresi Linier Berganda

Hasil analisis regresi linier berganda pada penelitian ini menggunakan SPSS versi 20 dapat dilihat pada Tabel 3.5.

\section{Tabel 3.5}

Hasil Analisis Regresi Linier Berganda Coefficients $^{\mathrm{a}}$

\begin{tabular}{|l|r|r|r|}
\hline \multirow{2}{*}{ Model } & \multicolumn{2}{|c|}{$\begin{array}{c}\text { Unstandardized } \\
\text { Coefficients }\end{array}$} & $\begin{array}{c}\text { Standardized } \\
\text { Coefficients }\end{array}$ \\
\cline { 2 - 4 } & \multicolumn{1}{|c|}{ B } & Std. Error & \multicolumn{1}{c|}{ Beta } \\
\hline \multirow{2}{*}{ (Constant) } & 15214,061 & 2343,778 & \\
1 CR & $-2112,451$ & 400,217 &,- 567 \\
DER & $-4386,989$ & 1168,025 &,- 419 \\
ROE & $-12691,875$ & 8218,380 &,- 164 \\
\hline
\end{tabular}

a. Dependent Variable: Harga Saham

Sumber: Hasil Pengolahan Data SPSS 20

Berdasarkan Tabel 3.5, model persamaan regresi yang diperoleh adalah sebagai berikut: $\hat{\mathrm{Y}}=15.214,061-2.112,451 \mathrm{X}_{1}-4.386,989 \mathrm{X}_{2}-12.691,875 \mathrm{X}_{3}$

Artinya, likuiditas, solvabilitas dan profitabilitas berpengaruh negatif terhadap harga saham pada Perusahaan yang Terdaftar Dalam Indeks LQ 45 Tahun 2013-2017.

\subsubsection{Koefisien Korelasi dan Determinasi}

Hasil koefisien korelasi dan koefisien determinasi dapa dilihat pada Tabel 3.6.

$$
\text { Tabel } 3.6
$$

Koefisien Korelasi dan Koefisien Determinasi Model Summary ${ }^{b}$

\begin{tabular}{|l|c|r|r|r|}
\hline Model & $R$ & $\begin{array}{c}\mathrm{R} \\
\text { Square }\end{array}$ & $\begin{array}{r}\text { Adjusted } \\
\text { R Square }\end{array}$ & $\begin{array}{c}\text { Std. Error of the } \\
\text { Estimate }\end{array}$ \\
\hline 1 &, $554^{\mathrm{a}}$ &, 307 &, 278 & 4222,996870 \\
\hline
\end{tabular}

b. Dependent Variable: Harga Saham

Sumber: Hasil Pengolahan DataSPSS 20

Dari Tabel 3.6, nilai $r$ adalah 0,554 yang berarti terdapat korelasi atau hubungan yang sedang antara variabel terikat (Harga Saham) dengan variabel bebas (CR, DER, dan ROE). Sementara koefisien determinasi (RSquare)sebesar 0,307, yang berarti 30,7\% dari variabel harga sahamdijelaskan oleh variabel likuiditas, solvabilitas dan profitabilitas sisanya $69,3 \%$ dijelaskan oleh variabel lain yang tidak diteliti dalam penelitian ini.

\subsubsection{Uji Hipotesis}

1. Uji Simultan (Uji F)

Hasil uji F dapat dilihat pada Tabel 3.7.

Tabel 3.7

Hasil Uji F

ANOVA $^{\mathrm{a}}$

\begin{tabular}{|l|r|r|}
\hline Model & $\mathrm{F}$ & \multicolumn{1}{|c|}{ Sig. } \\
\hline \multicolumn{1}{|c|}{$\begin{array}{l}\text { Regression } \\
\text { Residual } \\
\text { Total }\end{array}$} & 10,505 &, $000^{\mathrm{b}}$ \\
\hline
\end{tabular}

a. Dependent Variable: Harga Saham

b. Predictors: (Constant), ROE, CR, DER

Sumber: Hasil Pengolahan Data SPSS 20

Dari Tabel 3.7 di atas, diperoleh nilai signifikansi $0,000<0,05$ maka $\mathrm{H}_{0}$ ditolak, berarti likuiditas, solvabilitas dan profitabilitas berpengaruh signifikan terhadap harga saham pada Perusahaan yang Terdaftar Dalam Indeks LQ 45.

\section{Uji Parsial (Uji t)}

Hasil uji t dapat dilihat pada Tabel 3.8.

\section{Tabel 3.8}

Hasil Uji t

Coefficients $^{\mathrm{a}}$

\begin{tabular}{|l|r|r|r|}
\hline Model & $\begin{array}{c}\text { Standardized } \\
\text { Coefficients }\end{array}$ & \multicolumn{1}{c|}{$\mathrm{t}$} & \multicolumn{1}{c|}{ Sig. } \\
\cline { 2 - 3 } & \multicolumn{1}{|c|}{ Beta } & &, 000 \\
\cline { 1 - 2 } (Constant) &,- 567 & $-5,278$ &, 000 \\
CR &,- 419 & $-3,756$ &, 000 \\
DER &,- 164 & $-1,544$ &, 127 \\
\hline
\end{tabular}

a. Dependent Variable: Harga Saham

Sumber: Hasil Pengolahan Data

Dari Tabel 3.8di atas, Likuiditas mempunyai nilai signifikansi $0,000<0,05$ maka $\mathrm{H}_{0}$ ditolak, artinya likuiditas berpengaruh signifikan terhadap harga saham. Solvabilitas mempunyai nilai signifikansi $0,000<0,05$ maka $\mathrm{H}_{0}$ ditolak, artinya solvabilitasberpengaruh signifikan terhadap harga saham. Profitabilitas mempunyai nilai signifikansi 0,127 >0,05 maka $\mathrm{H}_{0}$ diterima, artinya profitabilitas berpengaruh tidak signifikan pada Perusahaan yang Terdaftar Dalam Indeks LQ 45.

\subsection{Evaluasi}

3.2.1. Evaluasi Likuiditas pada Perusahaan yang Terdaftar Dalam Indeks LQ 45 Tahun 2013-2016

Dari hasil penelitian, diperoleh rata-rata nilai rasio lancar pada Perusahaan yang Terdaftar Dalam Indeks LQ 45 tahun 2013-2017 berfluktuasi dan cenderung meningkat. Hal ini disebabkan oleh peningkatan aset lancar yang jauh lebih besar dari peningkatan kewajiban lancarnya. Peningkatan aset lancar tersebut dapat dilihat dari kas dan setara kas, piutang usaha dan persediaan perusahaan. Beberapa Perusahaan yang Terdaftar Dalam Indeks LQ 45 mengalami peningkatan pada kas dan setara kas, piutang usaha dan persediaan 
selama periode 2013-2017. Perusahaan yang mengalami peningkatan tersebut yaitu AALI, ASII, ICBP, INDF, KLBF, LPKR dan TLKM.

Berdasarkan uraian di atas, perusahaaan tidak memiliki kendala dalam memenuhi kewajiban jangka pendeknya. Namun, untuk mengoptimalkan nilai rasio lancar sebaiknya perusahaan mengelola aset lancar seperti kas dan setara kas, persediaan dan piutang untuk meningkatkan pendapatan, pendapatan yang meningkat akan berdampak pada laba perusahaan yang meningkat. Laba yang meningkat akan menjadi daya tarik investor untuk berinvestasi.

\subsubsection{Evaluasi Solvabilitas pada Perusahaan yang Terdaftar Dalam Indeks LQ 45 Tahun 2013-2016}

Dari hasil penelitian, diperoleh nilai rata-rata debt to equity ratio pada Perusahaan yang Terdaftar Dalam Indeks LQ 45 berfluktuasi dan cenderung menurun. Hal ini disebabkan oleh jumlah total utang tidak dapat mengimbangi jumlah ekuitas perusahaan. Besarnya total ekuitas yang dimiliki perusahaan dapat dilihat dari saldo laba yang meningkat. Saldo laba perusahaan mengalami peningkatan setiap tahunnya. Peningkatan ini disebabkan karena perusahaan menjadikan laba yang dihasilkan untuk tambahan modal sehingga total ekuitas meningkat.

Sebaiknya perusahaan dengan tingkat pengembalian yang lebih tinggi atas investasinya lebih cenderung menggunakan utang yang relatif kecil, karena perusahaan dianggap telah mampu menyediakan dana yang cukup dari aset dan ekuitas yang dimiliki perusahaan.

\subsubsection{Evaluasi Profitabilitas pada Perusahaan yang Terdaftar Dalam Indeks LQ 45 Tahun 2013-2016}

Dari hasil penelitian, diperoleh nilai rata-rata pengembalian atas ekuitas pada Perusahaan yang Terdaftar Dalam Indeks LQ 45 tahun 2013-2017 berfluktuasi dan cenderung menurun. Hal ini disebabkan karena peningkatan laba bersih yang tidak sebanding dengan kenaikan total ekuitas perusahaan. Peningkatan total ekuitas dapat dilihat dari saldo laba perusahaan yang mengalami peningkatan setiap tahunnya. Besarnya saldo laba tersebut disebabkan karena perusahaan menggunakan laba yang dihasilkan untuk tambahan modal sehingga total ekuitas perusahaan meningkat. Hal ini menunjukkan bahwa perusahaan tidak membagikan dividennya kepada para investor. Untuk meningkatkan profitabilitas sebaiknya perusahaan mengurangi ekuitas yang dimiliki dengan cara membagikan dividen kepada para investor sehingga investor tertarik untuk berinvestasi.

\subsubsection{Evaluasi Harga Saham pada Perusahaan yang Terdaftar Dalam Indeks LQ 45 Tahun 2013-2016}

Dari hasil penelitian, diperoleh nilai rata-rata harga saham pada Perusahaan yang Terdaftar dalam Indeks LQ 45 tahun 2013-2017 berfluktuasi dan cenderung menurun. Naik turunnya harga saham disebabkan oleh tidak stabilnya kinerja keuangan perusahaan. Kinerja keuangan tersebut dapat dilihat dari rasio likuiditas, solvabilitas dan profitabilitas. Berdasarkan analisis sebelumnya diketahui bahwa profitabilitas perusahaan mengalami penurunan. Profitabilitas yang menurun menyebabkan investor tidak tertarik untuk menanamkan modalnya di perusahaan tersebut sehingga harga saham perusahaan menurun. Untuk meningkatkan harga sahamnya, sebaiknya perusahaan melakukan pengendalian yang baik terhadap manajemen aset, manajemen utang dan ekuitas yang dimiliki perusahaan untuk meningkatkan kemampulabaan perusahaan, meningkatnya profitabilitas perusahaan akan menjadi daya tarik investor untuk berinvestasi sehingga harga saham pun meningkat.

3.5. Evaluasi Pengaruh

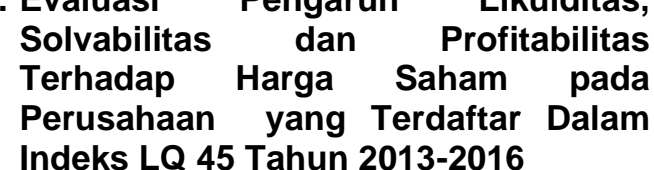

Berdasarkan hasil regresi diketahui bahwa likuiditas, solvabilitas dan profitabilitasmemiliki pengaruh negatif terhadap harga saham. Besar pengaruh yang dimaksud untuk konstanta adalah 15.214,061 yang secara sistematis menyatakan bahwa jika nilai variabel bebas likuiditas, solvabilitas dan profitabilitas bernilai nol maka nilai dari harga saham adalah 15.214,061. Likuiditas sebesar $-2.112,451$ berarti bahwa setiap kenaikan likuiditassebesar satu satuan, harga sahamakan menurun sebesar 2.112,451 satuan dengan asumsi variabel lain konstan dan sebaliknya.Solvabilitas sebesar $-4.386,989$ berarti bahwa setiap kenaikan solvabilitas sebesar satu satuan, harga sahamakan menurun sebesar 4.386,989 satuan dengan asumsi variabel lain konstan dan sebaliknya. Profitabilitas sebesar $-12.691,875$ berari bahwa setiap kenaikan profitabilitas sebesar satu satuan, harga saham akan menurun sebesar $12.691,875$ satuan dengan asumsi variabel lain konstan dan sebaliknya.

\section{KESIMPULAN DAN SARAN}

3.1. Kesimpulan

1. Nilai rata-rata rasio lancar pada Perusahaan yang Terdaftar Dalam Indeks 
LQ 45 tahun 2013-2017 mengalami fluktuasi dan cenderung meningkat. Namun terdapat beberapa perusahaan di bawah rata-rata yaitu AALI, AKRA, ASII, ASRI, INDF, JSMR, SMGR dan TLKM.

2. Nilai rata-rata Debt to Equity Ratio (DER) pada Perusahaan yang Terdaftar Dalam Indeks LQ 45 mengalami fluktuasi cenderung menurun. Namun terdapat beberapa perusahaan di bawah rata-rata yaitu AALI, BSDE, CPIN, ICBP, KLBF, LSIP, PTBA, SMGR dan TLKM.

3. Nilai rata-rata pengembalian atas ekuitas pada Perusahaan yang Terdaftar Dalam Indeks LQ 45 tahun 2013-2017 mengalami fluktuasi dan cenderung menurun. Namun terdapat beberapa perusahaan di bawah rata-rata yaitu AALI, AKRA, ASRI, INDF, JSMR, LPKR dan LSIP.

4. Nilai rata-rata harga saham Perusahaan yang Terdaftar Dalam Indeks LQ 45 tahun 2013-2017 mengalami fluktuasi dan cenderung menurun. Namun terdapat beberapa perusahaan di bawah rata-rata yaitu ASRI, BSDE, CPIN, KLBF, LPKR, LSIP, PTBA dan TLKM.

5. Dari hasil analisis regresi linier berganda diketahui bahwa likuiditas, solvabilitas dan profitabilitas berpengaruh negatif terhadap harga saham pada Perusahaan yang Terdaftar Dalam Indeks LQ 45 Tahun 2013-2017.

6. Dari hasil uji koefisien korelasi dan koefisien determinasi diketahui bahwa terdapat hubungan yang sedang antara likuiditas, solvabilitas dan profitabilitas terhadap harga saham dan harga saham lebih banyak dipengaruhi oleh faktor lain yang tidak diteliti dalam penelitian ini.

7. Dari hasil uji $F$ diketahui bahwa likuiditas, solvabilitas dan profitabilitas berpengaruh signifikan terhadap harga saham pada Perusahaan yang Terdaftar Dalam Indeks LQ 45.

8. Dari hasil uji t diperoleh bahwa likuiditas dan solvabilitas berpengaruh signifikan dan profitabilitas berpengaruh tidak signifikan terhadap harga saham pada Perusahaan yang Terdaftar Dalam Indeks LQ 45.

\subsection{Saran}

1. Sebaiknya perusahaan mengelola aset lancar dengan optimal seperti kas dan setara kas, persediaan dan piutang untuk meningkatkan pendapatan, pendapatan yang meningkat akan berdampak pada laba perusahaan yang meningkat. Laba yang meningkat akan menjadi daya tarik investor untuk berinvestasi.

2. Sebaiknya perusahaan dengan tingkat pengembalian yang lebih tinggi atas investasinya lebih cenderung menggunakan utang yang relatif kecil, karena perusahaan dianggap telah mampu menyediakan dana yang cukup dari aset dan ekuitas yang dimiliki perusahaan.

3. Sebaiknya perusahaan membagikan dividen agar investor tertarik untuk berinvestasi yang akan berdampak meningkatnya harga saham perusahaan.

4. Sebaiknya perusahaan melakukan pengendalian yang baik terhadap manajemen aset, manajemen utang dan ekuitas yang dimiliki perusahaan untuk meningkatkan kemampulabaan perusahaan, meningkatnya profitabilitas perusahaan akan menjadi daya tarik investor untuk berinvestasi sehingga harga saham pun meningkat.

\section{DAFTAR PUSTAKA}

Brigham, Eugene $F$, dan Joel F. Houston. 2006. Dasar-dasar Manajemen Keuangan. Buku 2, Edisi X. Jakarta: Salemba Empat.

2010. Dasar-dasar Manajemen Keuangan. Buku 1, Edisi XI. Jakarta: Salemba Empat.

Budiman, Raymond. 2017. Investing is Easy : Teknik Analisa dan Strategi Investasi Saham untuk Pemula. Jakarta: Elex Media Komputindo.

Fahmi, Irham. 2015. Analisis Laporan Keuangan. Bandung: Alfabeta.

Harahap, S. Syafri. 2008. Analisis Kritis Atas Laporan Keuangan. Jakarta: Rajawali Persada.

2011. Teori Akuntansi. Edisi Revisi. Jakarta: PT Raja Grafindo Persada.

Hery. 2014. Analisis Kinerja Manajemen. Jakarta: PT Grasindo.

2017. Teori Akuntansi Pendekatan Konsep dan Analisis. Jakarta: PT Grasindo.

Kasmir. 2015. Analisis Laporan Keuangan. Edisi VIII, Cetakan Kedelapan. Jakarta: Rajawali Pers.

Rudianto. 2009. Pengantar Akuntansi. Jakarta: Erlangga. 
Soemarso, S. R. 2009. Akuntansi Suatu Pengantar, Buku 2 Edisi kelima. Jakarta: Salemba Empat.

Sudana, I Made. 2011.

Praktek. Jakarta: Erlangga.
Widoatmodjo, Sawidji. 2005. Cara Sehat Investasi di Pasar Modal. Jakarta: PT Elex Media Komputindo.

Yadiati, Winwin, dan Ilham Wahyudi. 2010.

Pengantar Akuntansi. Cetakan Ketiga. Jakarta: Kencana. 